\title{
Herbicide Treatment and Vegetation Response to Treatment of Mesquites in Southern New Mexico
}

\author{
CARLTON H. HERBEL, WALTER L. GOULD, WILLIAM F. LEIFESTE, AND ROBERT P. GIBBENS
}

\begin{abstract}
Mesquite (Prosopis juliflora) is a major unwanted plant in the Southwest. This study evaluated the herbage responses obtained from various aerial applications of 2,4,5-T on mesquites in southern New Mexico. The dead plants on the various areas ranged from $7-64 \%$ of the mesquite. Yields of perennial grasses ranged from $3-1931 \mathrm{~kg} / \mathrm{ha}$ on the untreated controls and $11-2696 \mathrm{~kg} / \mathrm{ha}$ on the areas sprayed with 2,4,5-T. In dense stands of mesquite, about $30 \%$ of the mesquites must be killed before grass yields are significantly increased.
\end{abstract}

There are an estimated 38 million ha of land infested with mesquite [Prosopis juliflora (Swartz) DC.] in the United States (Platt 1959). An estimated 4 million ha occur in New Mexico (Sampson and Schultz 1956). Although mesquite is an indigenous plant, it has invaded large areas and has become dominant on some of these in the last 100 years (Norris 1950, Wright 1960, Paulsen and Ares 1962, Buffington and Herbel 1965, York and DickPeddie 1969). The invasion and increase of mesquites have resulted in a decrease in cover and production of the perennial grass plants that once dominated these areas. As mesquites become established, an area devoid of herbaceous vegetation develops around the maturing mesquite plants. As the herbaceous cover is depleted wind erosion becomes more severe, particularly on sandy rangelands of the Southwest. Eventually, the " $A$ "horizon and part of the " $B$ " horizon is deposited around the mesquite or removed from the area entirely, resulting in a further decrease of the desirable perennial herbaceous plants and a build-up of sand dunes. Because of the competition for soil water by mesquite, few herbaceous plants become established on the eroded soils unless the mesquite is controlled.

The aerial application of 2,4,5-T [ (2,4,5-trichlorophenoxy)acetic acid] has resulted in the control of mesquites and increased grass production in Arizona (Cable and Tschirley 1961) and in Texas (Fisher et al. 1959). This study was conducted to evaluate the degree of mesquite control resulting from aerial applications of 2,4,5-T in New Mexico and to determine whether control of mesquites on depleted rangelands in southern New Mexico would restore them to a more productive condition.

\section{Methods and Materials}

This study was conducted at 5 locations in southeastern New Mexico and 1 location in south central New Mexico (Fig. 1). The soils of the 5 sites in southeastern New Mexico are in 2 general

Herbel and Gibbens are range scientists, Jornada Experimental Range, Agricultural Research Service, USDA, Las Cruces, New Mexico 88003; Gould is weed physiologist, New Mexico State University, Las Cruces; Leifeste chief (now retired), Division of Resource Management, Bureau of Land Management, USDI, Las Cruces, N. Mex. 88001 .

Cooperative investigations of U.S. Department of Agriculture, Agricultural Research Service, and the New Mexico Agricultural Experiment Station. Published as journal article number 907 . Agricultural Experiment Station, New Mexico State University, Las Cruces, New Mex. 88003

Manuscript received February 24, 1982 associations, the Upton-Simona association (shallower soils) and the Kermit-Maljamar-Berino association (Maker et al. 1970). The soils of the Jornada site are in the Simona-Harrisburg association (Bulloch and Neher 1980). These soils have a sandy surface that are quite susceptible to wind erosion. The surface relief is undulating or duned. The vegetation on the deeper sands in southeastern New Mexico is dominantly tall and mid-grasses, mesquite, sand shinnery oak [Quercus havardi Rydb.)] and sand sagebrush [Artemisia filifolia (Torr.)]. The more shallow soils support short and mid-grasses, mesquite, broom snakeweed [Xanthocephalum sarothrae (Pursh) Shinners] and some creosotebush [Larrea tridentata (DC.) Cov.]. The average annual precipitation varies from $258 \mathrm{~mm}$ at the Ochoa Weather Station in the southeast portion of the study area to $313 \mathrm{~mm}$ at Roswell. The study site on the Jornada Experimental Range is dominated by mesquite, broom snakeweed, and short and mid-grasses. The average precipitation is $225 \mathrm{~mm}$.

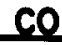

- santa fe

-aleuquerque

NM

$\triangle D A$

OROSWELL

$\Delta 0$

- LAS CRUCES

CARLSADO

ARTESIA

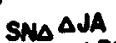

$T \times$

ACLIPPING SITE

ig. 1. Treatment sites and some major cities in New Mexico. $(B A=B a t e s$, $B R=$ Brinninstool, $D A=$ Daniels, $J A=$ James, $J O=J o r n a d a$, and $S N$ $=$ Snyder). 
Low-volatile ester formulations of 2,4,5-T were aerially applied in the mornings when wind velocities and temperatures were relatively low. The $2,4,5-T$ was applied at the rate of $0.6 \mathrm{~kg} / \mathrm{ha}$ acid equivalent except at the Brinninstool site, where it was $0.8 \mathrm{~kg} / \mathrm{ha}$. The 2,4,5-T was applied in a 1:5 or 1:7 diesel oil to water emulsion at a total volume of 47 liters/ha. The effects of the treatment on mesquites were determined the third fall after the herbicide was applied by counting 100-plant groups. Each plant was classified as dead or alive. Mesquite plants growing in sand dunes were considered 4-12 plants depending on the size of the dune. Thus, if the estimated number on a dune was 9 plants and $2 / 3$ of the mesquites were dead, we would count it as 6 dead plants and 3 live plants. From 16-100 plant groups were counted at each site in southeastern New Mexico depending upon the size of the sprayed area. On the Jornada Experimental Range, 20-22 plant groups were counted on each sprayed area.

The basal cover and yield of perennial grasses, and the canopy cover of mesquites were measured on adjacent sprayed and unsprayed areas approximately $150 \mathrm{~m}$ apart utilizing a line intercept and belt transect as described by Canfield (1941). A single observation consisted of a line intercept transect, $30.5 \mathrm{~m}$ long, to determine basal cover of perennial grasses and canopy cover of live mesquites. Along the same transect the perennial grasses on a $5.1-\mathrm{cm} \times 30.5 \mathrm{~m}$ belt transect were clipped to ground level, old growth was removed and discarded, the current year's growth was air-dried for 30 days and then weighed to determine yield of the perennial grasses. Fourteen transects were observed at each site in southeastern New Mexico in 1966, and 25 transects per site were observed in 1967 and 1968, except at the Daniel's site where only 8 transects were observed in 1967.

\section{Results and Discussion}

A total of 277 100-plant groups were counted in southeastern New Mexico to determine mesquite mortality. The amount of mesquite killed ranged from $7-50 \%$ (Table 1 ) with an average mortality of $36 \%$. Very low mortality was obtained on areas where mesquite were damaged by insects or rodents, were defoliated by hard freezes prior to spraying, or because mesquites were in low vigor due to low precipitation for several months prior to spraying. At the Jornada site the percent of mesquite killed yearly by one application of 2,4,5-T from 1958 through 1961 was $18,30,9$, and 13 , respectively. Greater than additive effects resulted from 2 appli- cations of herbicide with kill from treatments in $1958+1960$ being $31 \%, 50 \%$ on the site sprayed in $1958+1961$ and $64 \%$ on the $1959+$ 1961 site. The mortality of mesquites was definitely related to plant vigor as reflected by precipitation received in the several months prior to treatment (Valentine and Norris 1960). In 1958 the January through May precipitation was $113 \mathrm{~mm}$ and the September through December precipitation was $151 \mathrm{~mm}$. Precipitation in the early months of 1958 enhanced plant vigor, and a moderate degree of kill was obtained. The rainfall late in 1958 apparently carried over in 1959 to promote vigorous mesquite growth and resulted in a high level of mortality. The low winter-spring moisture preceeding the 1960 and 1961 sprayings $(20 \mathrm{~mm})$ resulted in a low level of control. Similarly, low mesquite mortality was obtained in southeastern New Mexico in years when precipitation during the 6months prior to spraying was less than $63 \mathrm{~mm}$ (Leifeste 1971).

Mesquite canopy ranged from $0.6-6.3 \%$ cover on the sprayed areas in southeastern New Mexico, 3 growing seasons after spraying, and $4.9-21.1 \%$ cover on the adjacent untreated areas. On the Bates site sprayed in 1964 with a kill of $7 \%$, the mesquite canopy cover was $4.0 \%$ in 1965 and $6.3 \%$ in 1966 , as compared to $12 \%$ cover on the unsprayed areas. This demonstrates the rapidity of mesquite regrowth. On the other sprayed sites the mesquite canopy cover ranged up to $3.5 \%$ at the date of final evaluation. Excluding the 1964 Bates site, the mesquite canopy cover averaged $1.9 \%$ on the sprayed areas and $8.9 \%$ on the unsprayed areas for an average canopy reduction of $79 \%$. On the Jornada site, the mesquite canopy cover at the last date of evaluation averaged $3.0 \%$ on the sprayed sites and $13.1 \%$ on the untreated areas.

The cover of perennial grasses varied from site-to-site and yearto-year. It ranged from $0.05-3.5 \%$ on sprayed sites and $0.06-2.0 \%$ on the unsprayed controls in southeastern New Mexico. On the Jornada site, the average cover of perennial grasses in 1965-1967 on the areas sprayed in $1958+1960,1958+1961$, and $1959+1961$ was $0.11,0.17$, and $0.08 \%$, respectively. On the untreated areas it averaged $0.02 \%$.

Where mesquite growth is inhibiting forage production, a favorable herbage response to mesquite control depends on site condition before treatment, degree of kills of mesquite plants, favorable precipitation, and deferment from grazing by livestock. Leifeste (1971) concluded there must be a minimum of a $30 \%$ kill of mesquite to obtain significant response of the desirable herbage plants. In addition there must be sufficient deferment from livestock grazing during the growing season following herbicide appli-

Table 1. Dead mesquite plants, and yield (kg/ha) of perennial grasses on adjacent treated and untreated areas at 6 sites in southeastern New Mexico.

\begin{tabular}{|c|c|c|c|c|c|}
\hline \multirow[b]{3}{*}{ Name and year of treatment } & \multirow{3}{*}{$\frac{\text { Dead plants }}{\%}$} & \multicolumn{4}{|c|}{ Production \pm 0.95 confidence interval } \\
\hline & & 1965 & 1966 & 1967 & Average \\
\hline & & $(\mathrm{kg})$ & $(\mathrm{kg})$ & $(\mathrm{kg})$ & $(\mathrm{kg})$ \\
\hline $\begin{array}{l}\text { Bates } 1959 \\
\text { Sprayed } \\
\text { Unsprayed }\end{array}$ & $\begin{array}{r}38 \\
0\end{array}$ & $\begin{array}{r}1279 \pm 181 \\
771 \pm 208\end{array}$ & $\begin{array}{l}2304 \pm 269 \\
1687 \pm 325\end{array}$ & $\begin{array}{l}2696 \pm 283 \\
1931 \pm 325\end{array}$ & $\begin{array}{l}2093 \\
1463\end{array}$ \\
\hline $\begin{array}{l}\text { Bates } 1964 \\
\text { Sprayed } \\
\text { Unsprayed }\end{array}$ & $\begin{array}{l}7 \\
0\end{array}$ & $\begin{array}{l}457 \pm 139 \\
423 \pm 111\end{array}$ & $\begin{array}{l}340 \pm 48 \\
375 \pm 102\end{array}$ & $\begin{array}{l}552 \pm 110 \\
430 \pm 73\end{array}$ & $\begin{array}{l}450 \\
409\end{array}$ \\
\hline $\begin{array}{l}\text { James } 1961 \\
\text { Sprayed } \\
\text { Unsprayed }\end{array}$ & $\begin{array}{r}46 \\
0\end{array}$ & $\begin{array}{l}268 \pm 110 \\
223 \pm 86\end{array}$ & $\begin{array}{l}295 \pm 87 \\
137 \pm 59\end{array}$ & $\begin{array}{r}363 \pm 169 \\
83 \pm \quad 27\end{array}$ & $\begin{array}{l}309 \\
148\end{array}$ \\
\hline $\begin{array}{l}\text { Daniels } 1962+1965 \\
\text { Sprayed } \\
\text { Unsprayed }\end{array}$ & $\begin{array}{r}48 \\
0\end{array}$ & $\begin{array}{l}529 \pm 82 \\
440 \pm 59\end{array}$ & $\begin{array}{l}561 \pm 71 \\
445 \pm 78\end{array}$ & $\begin{array}{l}279 \pm 86 \\
129 \pm 52\end{array}$ & $\begin{array}{l}456 \\
338\end{array}$ \\
\hline $\begin{array}{l}\text { Synder } 1963 \\
\text { Sprayed } \\
\text { Unsprayed }\end{array}$ & $\begin{array}{r}31 \\
0\end{array}$ & $\begin{array}{l}167 \pm 54 \\
152 \pm 76\end{array}$ & $\begin{array}{l}258 \pm 44 \\
171 \pm 60\end{array}$ & $\begin{array}{l}360 \pm 108 \\
330 \pm 103\end{array}$ & $\begin{array}{l}261 \\
218\end{array}$ \\
\hline $\begin{array}{l}\text { Brinninstool } 1965 \\
\text { Sprayed } \\
\text { Unsprayed }\end{array}$ & $\begin{array}{r}50 \\
0\end{array}$ & $\begin{array}{l}77 \pm 57 \\
64 \pm 69\end{array}$ & $\begin{array}{r}211 \pm 74 \\
80 \pm 49\end{array}$ & $\begin{array}{r}519 \pm 44 \\
94 \pm 43\end{array}$ & $\begin{array}{r}269 \\
79\end{array}$ \\
\hline
\end{tabular}


cation to allow the desirable plants to regain their vigor and seedlings to become established. In some instances it takes several years for the treatment to result in significant herbage responses, e.g., the James site treated in 1961 and the Daniels site treated in 1962 and again in 1965 (Table 1). The Snyder pasture was not deferred after spraying. The rainfall in southeastern New Mexico in 1963-67 varied from 50-70\% of average and the rainfall for June through September in these years varied from $57-87 \%$ of average. The combination of grazing pressure and low rainfall was not conducive to the establishment of new seedlings.

At the Jornada site, production of perennial grasses varied widely from year to year and place to place depending on precipitation and the stand of the grasses (Figure 2). The average yields of the three treated sites ranged from $36-248 \mathrm{~kg} / \mathrm{ha}$ for $1963-66$. Then it was above $200 \mathrm{~kg} / \mathrm{ha}$ for the next 4 ycars, dropped to $65 \mathrm{~kg} / \mathrm{ha}$ in 1971 , was about $155 \mathrm{~kg}$ / ha for the next 4 years, and averaged 399 $\mathrm{kg} /$ ha for 1976. Crop year precipitation (October-September) was above $200 \mathrm{~mm}$ for $1966-70$ but in 1971 it was $158 \mathrm{~mm}$. Even though precipitation was above $300 \mathrm{~mm}$ for 1972-75, average grass production was low because the stand of perennial grasses was severely reduced by the severe drought of 1970-71. During 1963-73 average production of perennial grasses on the adjacent untreated area was $20 \%$ of that on the treated area. These paired samples were taken about $150 \mathrm{~m}$ apart so that sprayed and untreated sites would have similar environments. The production of perennial grasses in 1971 on an untreated area about $\mathbf{l} \mathrm{km}$ from the sprayed area was approximately $5 \%$ of the production on the area sprayed from mesquite control (Gould, unpublished data). The stand of grass along the border of the sprayed and unsprayed area was relatively high and decreased sharply with distance into the untreated area. Apparently, the sprayed area served as a seed source of the desirable perennial grasses.

\section{Conclusions}

Control of mesquites in arid areas can be achieved with the aerial application of 2,4,5-T provided the mesquites are undamaged (e.g., by frost, wind, or insects) and growing actively at the time of treatment. In dense stands of mesquites, about $30 \%$ of the brush must be killed before a significant increase in grass yield can be obtained. In this study, the reduction of mesquite canopy cover to $3 \%$ or less resulted in a positive grass response to the spray treatment. The amount of mesquite killed is greatly affected by amount of precipitation during the 6 months prior to spraying. A minimum of $63 \mathrm{~mm}$ of precipitation (i.e., average or above) must occur during this period to obtain a minimum kill of $30 \%$.

A significant increase in grass yield following mesquite control occurs only if proper grazing management is practiced. The major items are deferment from livestock grazing so existing herbaceous plants may improve their vigor and so that new seedlings may become established. Seedling establishment is uncertain in the arid Southwest so flexibility in the grazing operation must be maintained to provide the needed deferment during seedling establishment when there is sufficient moisture.

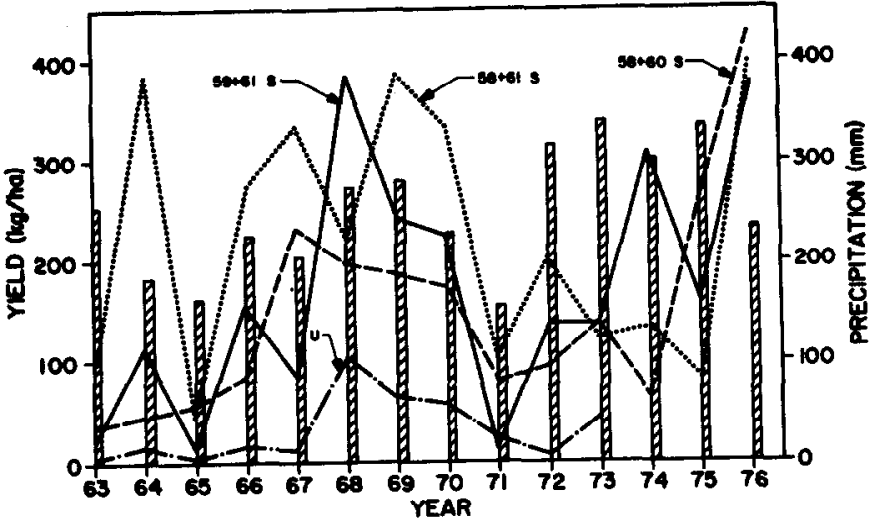

Fig. 2. Precipitation (mm) during the crop year (October-September) and perennial grass production $(\mathrm{kg} / \mathrm{ha})$ on areas sprayed (S) twice for mesquite control, $1958+1960,1958+1961$, and $1959+1961$, and an adjacent untreated $(U)$ area on the Jornada Experimental Range.

\section{Literature Cited}

Buffington, L.C., and C.H. Herbel. 1965. Vegetational changes on a semidesert grassland range from 1858 to 1963. Ecol. Monog. 35:139-164.

Bulloch, H.E., Jr., and R.E. Neher. 1980. Soil survey of Dona Ana County area of New Mexico. Soil Conserv. Serv., USDA, in cooperation with Bur. Land Manage., USDI and N. Mex. Agr. Exp. Sta.

Cable, D.R., and F.H. Tschirley. 1961. Response of native and introduced grasses following aerial spraying of velvet mesquite in southern Arizona. J. Range Manage. 14:155-159.

Canfield, R.H. 1941. Application of the line interception method in sampling range vegetation. J. Forestry 39:388-394.

Fisher, C.E., C.H. Meadors, R. Behrens, E.D. Robison, P.T. Marion, and H. L. Morton. 1959. Control of mesquite on grazing lands. Tex. Agr. Exp. Sta. Bull. 935.

Leifeste, W.F. 1971. Control of mesquite in southeastern New Mexico. MS Thesis, N. Mex. State Univ., Las Cruces.

Maker, H.J., V.C. Link, and J.U. Anderson. 1970. Soil associations and land classification for irrigation. N. Mex. Agr. Exp. Sta. Rep. 170.

Norris, J.J. 1950. Effect of rodents, rabbits, and cattle on two vegetation types in semidesert range land. N. Mex. Agr. Exp. Sta. Bull. 353.

Paulsen, H.A., Jr., and F.N. Ares. 1962. Grazing values and management of black grama and tobosa grasslands and associated shrub ranges of the Southwest. USDA Tech. Bull. 1270.

Platt, K.B. 1959. Plant control: some possibilities and limitations. J. Range Manage. 12:64-68.

Sampson, A.W., and A.M. Schultz. 1956. Control of brush and undesirable trees. Unasylva 10:19-29.

Valentine, K.A., and J.J. Norris. 1960. Mesquite control with 2,4,5-T by ground spray application. N. Mex. Agr. Exp. Sta. Bull. 451.

Wright, R.A. 1960. Increase of mesquite on a southern New Mexico range. MS Thesis, N. Mex. State Univ., Las Cruces.

York, J.C., and W.A. Dick-Peddie. 1969. Vegetative changes in southern New Mexico during the past hundred years, p. 157-166. In: Arid Lands in Perspective. Univ. Ariz. Press, Tucson. 